\title{
THE CONVERSION OF ISOSAFROLE TO PIPERONAL AND ANETHOLE TO ANISALDEHYDE: ELECTROCHEMICAL ACTIVE MANGANESE DIOXIDE
}

\author{
James Grimshaw* and Cheng Hua \\ School of Chemistry, Queen's University, Belfast BT9 5AG, U.K.
}

(Received 2 August 1993; in revised form 27 September 1993)

\begin{abstract}
Non-stoichiometric manganese dioxide prepared electrochemically at room temperature and suspended in dilute sulphuric acid is used to oxidise isosafrole to piperonal in $54 \%$ isolated yield. The manganese dioxide-manganese(II) sulphate system can be recycled electrochemically at high current density. It has the further advantage that water-soluble materials derived from the chemical oxidation step can be removed by filtration at the manganese dioxide stage. Direct oxidation of isosafrole at a lead dioxide anode leads to further oxidation of the piperonal.
\end{abstract}

Key words: oxidation, manganese dioxide, isosafrole, piperonal, anethole.

\section{INTRODUCTION}

Piperonal (2) has wide applications as an intermediate and in the formulation of fragrance and flavouring materials. The only technical scale source is from isosafrole (1) by chemical oxidation. One large scale process[1] uses chromium(VI) as the oxidant and is unsatisfactory because of the associated environmental problems. Ozone can be used as the oxidising agent[2] but this process requires the careful control of reaction temperatures $\left(0-5^{\circ} \mathrm{C}\right)$. A number of workers have looked for a satisfactory electrochemical process for both this conversion and the related conversion of anethole (4) to anisaldehyde (5).

Conversion of isosafrole to piperonal has been reported in a two-stage electrochemical process [3]. In the first stage, a bromine-mediated reaction leads to the diol (3) which is cleaved in a second electrochemical stage. Mediated, one-stage, electrochemical oxidation of isosafrole has been achieved with a ruthenium(IV) oxide-ruthenium(II) mediator[4] and also with a cerium(IV)-cerium(III) mediator[5].

The direct electrochemical oxidation of anethole as a suspension in aqueous sodium sulphate has been examined at a lead dioxide anode[6]. Anisaldehyde was obtained together with a substantial amount of anisic acid. Mediated oxidation by manganese(III)-manganese(II) converts anisole to anisaldehyde but the process requires $55 \%$ sulphuric acid to stabilise the manganese(III) species[7].

We decided to carry out a careful investigation of the oxidation of both anethole and isosafrole at a lead dioxide anode with the objective of obtaining a more satisfactory yield of the aldehydes than previously achieved. The work was extended to an examination of the mediated electrochemical oxidation of isosafrole using manganese salts and low con-

\footnotetext{
* Author to whom all correspondence should be
} addressed. centrations of sulphuric acid. In early references, $[8$, 9], electrochemically generated manganese(III) sulphate was used in weakly acid solution for the oxidation of organic substrates. The reagent hydrolyses to a brown precipitate which, in the recent literature[10], is believed to be a hydrated manganese dioxide. Our objective was to prepare this active manganese dioxide in such a way as to minimise the amount of sulphuric acid which is discharged at the end of the process.

\section{EXPERIMENTAL}

\section{General directions}

Preparative electrochemical experiments were carried out at constant current. A Pye-Unicam gas chromatography instrument was used for product analysis, fitted with a carbowax-20M column $\left(9 \mathrm{~m} \times 4 \mathrm{~mm}\right.$ ID) at $200^{\circ} \mathrm{C}$ and a flame ionization detector. Retention times: anethole, $3 \mathrm{~min}$; anisaldehyde, $5.2 \mathrm{~min}$; isosafrole, $4 \mathrm{~min}$ (two peaks due to cis- and trans-isomers); piperonal, $9.5 \mathrm{~min}$.

Where the reaction mixture was homogeneous, small samples $(5 \mathrm{ml})$ of the anolyte were taken for GLC and the organic products isolated with ether. Where the anolyte was not homogeneous, the whole product was extracted with ether. Ether extracts were concentrated to a standard volume and a standard amount injected onto the GLC column. Calibration was carried out with solutions of known concentration.

\section{Direct electrochemical oxidations}

Cylindrical beaker cells were used. The lead sheet anode and nickel foil cathode were arranged symmetrically and only one surface of the anode (area 20 or $100 \mathrm{~cm}^{3}$ ) was considered for calculation of current density. Anolyte and catholyte were separated with a diaphragm of porous pot.

Lead dioxide anodes were prepared by subjecting the lead anode to a constant current $\left(500 \mathrm{Am}^{-2}\right)$ for 
$30-45 \mathrm{~min}$ in $1 \mathrm{M}$ sulphuric acid until a uniform and stable brown layer was formed. The cathode was nickel foil in an undivided cell.

(a) Anethole (4). Anethole $(3.1 \mathrm{~g}, 0.0215 \mathrm{~mol})$ was dissolved or suspended in electrolyte $(150 \mathrm{ml})$. Reaction was performed at room temperature with vigorous stirring. Samples were taken at intervals for GLC control. When conversions were essentially complete the solvent was partly removed under reduced pressure, the products isolated with ether and washed with sodium carbonate, respectively. Anisaldehyde was identified by GLC and ir spectroscopy.

(b) Isosafrole (1). Isosafrole $(2.43 \mathrm{~g}, 0.0150 \mathrm{~mol})$ was dissolved or suspended in the electrolyte $(150 \mathrm{ml})$ and oxidised as for the previous example.

\section{Indirect oxidation by electrolytic manganese dioxide}

Active electrolytic manganese dioxide was prepared from a solution of manganese sulphate tetrahydrate $(45 \mathrm{~g}, 0.2 \mathrm{~mol})$ in $2 \mathrm{M}$ sulphuric acid $(500 \mathrm{ml})$ at a lead anode (current density $2 \times 10^{3} \mathrm{Am}^{-2}$, total charge passed $2.2 \mathrm{~F} \mathrm{~mol}^{-1}$ ). This was achieved in a FMO1 electrolyser (from ICI Ltd.) using a nickel cathode in $2 \mathrm{M}$ sulphuric acid and a two compartment arrangement with nafion membrane. The product formed a black sludge which was collected by filtration. On a smaller scale, this product was obtained in an individual beaker cell with lead anode and stainless steel cathode.

A mixture of isosafrole $(1.9 \mathrm{~g}, 0.015 \mathrm{~mol})$ and manganese dioxide prepared from manganese sulphate $(0.18 \mathrm{~mol})$ was stirred with $2 \mathrm{M}$ sulphuric acid $(100 \mathrm{ml})$ for $14 \mathrm{~h}$ at $60^{\circ} \mathrm{C}$. The reaction mixture was filtered hot and the aqueous and solid phases washed with chloroform. The chloroform layer was separated, washed with sodium carbonate solution and water, dried and the solvent removed to leave crude piperonal $(1.15 \mathrm{~g})$, recrystallised from warm water as colourless crystals $(0.95 \mathrm{~g}, 54 \%)$, m.p. $37-$ $38^{\circ} \mathrm{C}$.

\section{RESULTS AND DISCUSSION}

\section{Direct electrochemical oxidation}

The direct electrochemical oxidation of anethole is best carried out in aqueous alcohol at low current density, ca. $10 \mathrm{Am}^{-2}$. Chemical yields of anisaldehyde are satisfactory but the process is not efficient in terms of charge consumption and passage of up to 19 Faraday per mole is required. Results are summarised in Table 1. Sodium sulphate and sodium carbonate are suitable electrolytes.

On the basis of these results, an attempt was made to improve the yield of piperonal from the direct electrochemical oxidation of isosafrole. Sodium carbonate in $25 \%$ ethanol as electrolyte was unsatisfactory as the anode became poisoned after about $6 \mathrm{~h}$ and pitting corrosion set in.

Oxidation at lead dioxide in dilute sulphuric acid proceeded without deterioration of the anode surface for a period of over $20 \mathrm{~h}$. However, in all cases the yield of piperonal reached a maximum and then began to fall before all the isosafrole had been consumed. Reactions were monitored with time and Table 2 records conditions close to the time of maximum yield of piperonal. Changes in piperonal concentration during run no. 13 are given in Fig. 1. The consumption of piperonal by further oxidation is unacceptably rapid and it is unlikely that direct electrochemical oxidation at lead dioxide will be a satisfactory route to piperonal.

\section{Oxidation using manganese dioxide}

Manganese dioxide prepared electrochemically at room temperature forms a finely divided precipitate which will oxidise isosafrole. The wet reagent is

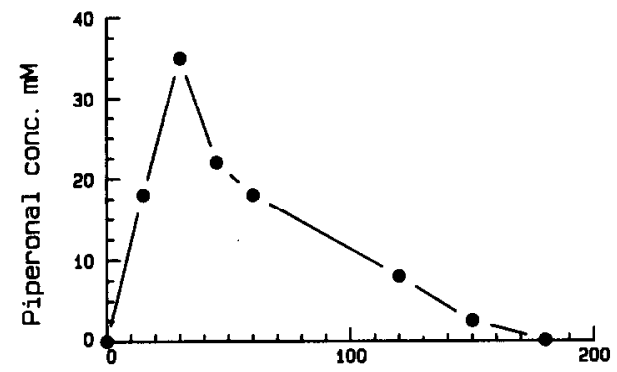

Charge passed F / mol isosafrole

Fig. 1. Yield of piperonal from the oxidation of isosafrole in a divided cell at a $\mathrm{PbO}_{2}$ anode, area $20 \mathrm{~cm}^{2}$. Current density $500 \mathrm{~A} \mathrm{~m}^{-2}$, initial isosafrole concentration $100 \mathrm{mM}$, anolyte of $25 \%$ ethanol, $75 \% 0.5 \mathrm{M}$ sulphuric acid, anolyte volume $150 \mathrm{ml}$

Table 1. Oxidation of anethole to anisaldehyde

\begin{tabular}{lcrcccc}
\hline Run No. & Current/A & Time/h & $\begin{array}{c}\text { Faraday/Mol } \\
\text { anethole }\end{array}$ & Solvent & $\begin{array}{c}\% \text { yield } \\
\text { Electrolyte }\end{array}$ & \% Conversion \\
anisaldehyde
\end{tabular}

Conditions: Each reaction employed $0.0215 \mathrm{~mol}$ anethole in $150 \mathrm{ml}$ solvent. ${ }^{*} \mathrm{~Pb}$ anode, $\mathrm{Ni}$ cathode, undivided cell, room temperature with vigorous stirring. † Performed $\mathrm{Pb} / \mathrm{PbO}_{2}$ anode, $\mathrm{Ni}$ cathode, divided cell, room temperature with vigorous stirring.

Current density: $\dagger 10 \mathrm{~A} \mathrm{~m}^{-2}, \S 100 \mathrm{~A} \mathrm{~m}^{-2}$.

Remarks: The anode surface eventually became blocked by a thick, soft layer. 
Table 2. Oxidation of isosafrole to piperonal

\begin{tabular}{ccccccc}
\hline Run No. & $\begin{array}{c}\text { Current } \\
\text { Density } \\
/ \text { A m }^{-2}\end{array}$ & $\begin{array}{c}\text { Current } \\
/ \mathrm{A}\end{array}$ & $\begin{array}{c}\text { Time* }^{*} \\
\text { /h }\end{array}$ & $\begin{array}{c}\text { Faraday/mol } \\
\text { isosafrole* }\end{array}$ & $\begin{array}{c}\% \\
\text { conversion }\end{array}$ & \% yield \\
\hline 9 & 100 & 0.50 & 22.4 & 28 & 49 & 21 \\
10 & 200 & 0.60 & 20.0 & 30 & 50 & 24 \\
11 & 300 & 0.75 & 16.0 & 30 & 56 & 28 \\
12 & 400 & 0.80 & 15.4 & 31 & 60 & 32 \\
13 & 500 & 1.00 & 12.6 & 31 & 60 & 35 \\
\hline
\end{tabular}

Conditions: Each reaction employed $0.015 \mathrm{~mol}$ isosafrole in solvent $(150 \mathrm{ml})$ of $25 \%$ ethanol, $75 \% 0.5 \mathrm{M}$ sulphuric acid, temperature $18^{\circ} \mathrm{C}$, preformed $\mathrm{Pb} / \mathrm{PbO}_{2}$ anode and nickel cathode in a divided cell.

Remarks: *Value at the point of maximum yield of piperonal.

non-stoichiometric in composition with a ratio of available oxygen to total manganese content corresponding to $\mathrm{MnO}_{1.8}$. Piperonal is obtained in $54 \%$ yield from the reaction with an excess of oxidising agent suspended in dilute sulphuric acid. The aqueous phase from this reaction contains manganese(II) ions which can be converted electrochemically to the active oxidising agent and thus reused. The manganese dioxide-manganese(II) system has been used in this way for the oxidation of 4-methoxytoluene to anisaldehyde[11].

The oxidation of isosafrole by electrolytically prepared cerium(IV) sulphate has been described in the literature[5] and gives piperonal in $83 \%$ yield. More recently, methanesulphonic acid has been suggested as a better solvent than sulphuric acid for oxidations with cerium salts [12]. Any indirect oxidation process, where the reagent is recycled electrochemically, must take into account the water soluble organic byproducts that are inevitably formed. In the case isosafrole, these byproducts will be derived from acetaldehyde and piperonal by further oxidation. Products retained in the aqueous phase which is sent for regeneration of the inorganic reagent will accumulate with each round of the process. Ultimately, some scheme has to be devised for their elimination. The manganese dioxide-manganese(II) system has a definite advantage here because the oxidant, manganese dioxide, is insoluble so that it can be separated by filtration and transferred to a clean solution for further reaction.

\section{CONCLUSIONS}

The oxidation of isosafrole with active manganese dioxide electrochemically prepared at room temperature gives a good yield of piperonal. The manganese reagent can be recycled electrochemically and water soluble organic byproducts can be eliminated by filtering the manganese dioxide. The process uses dilute sulphuric acid and discharges a minimum of waste reagents.

Activated manganese dioxide is well known as an oxidising agent in organic chemistry[13] where the reagent is usually prepared by reaction between manganese(II) and permanganate. We believe that it will be worthwhile to explore the use of the electrochemically prepared and recycled reagent.

\section{REFERENCES}

1. N. T. Farinaci, US Pat., 2794813 (1957); Chem. Abs. 51, 6572 (1957); A. V. Bogastskii, A. P. Antonov, Y. V. Gavyevich, V. V. Titor and V. Y. Kalashnikov, USSR Pat., 490793 (1975); Chem. Abs. 84, 74254 (1976).

2. International Corporation, Brit. Pat., 1092615 (1967); Chem. Abs. 69, 2516 (1968); E. A. Blair, US Pat., 2916499 (1959); Chem. Abs. 54, 6650 (1960).

3. S. Torii, K. Uneyama and K. Ueda, J. Org. Chem. 49, 1830 (1984).

4. J. M. Madurro, G. Chiericato, W. F. de Giovani and J. R. Romero, Tetrahedron Letters 29, 765 (1988).

5. J. P. Millington and D. A. Hughes, Brit. Pat. Appln., 2165536 (1986); Chem. Abs. 105, 153052 (1986).

6. F. Fichter and A. Christen, Helv. Chim. Acta 8, 332 (1925).

7. S. Chidambaram, M. S. V. Pathy and H. V. K. Udupa, J. Electrochem. Soc. India, 17, 95 (1968).

8. W. Lang, Ger. Pat., 166357 (1906); J.C.S. Abstracts 90, 627 (1906).

9. W. Lang, Ger. Pat., 189178 (1907); J.C.S. Abstracts 94, 350 (1908).

10. J. Ph. Petitpierre, Ch. Comninellis and E. Plattner, Electrochim. Acta 35, 281 (1990).

11. J. P. Millington, A. R. Jones, D. A. Hughes and J. E. Trotman, Brit. UK Pat. Appin., 2164935 (1986); Chem. Abs. 105, 1, 4728 (1986).

12. R. P. Krek and R. M. Spotnitz, US Pat., 4639298 (1987) and US Pat., 4670108 (1987); Chem. Abs. 106, 127956 (1987).

13. A. J. Fatiadi, Synthesis 65 and 133 (1976). 